\title{
Microbiological Quality Analysis of Popular Fluids and Drinks Sold in Bashundhara Residential Area, Dhaka
}

\author{
Tasmin Tabassum ${ }^{1}$, Tahsin Tabassum ${ }^{1}$, Asma Akter Bhuiyan ${ }^{1}$, Mehran Mosharraff Hossain Niloy ${ }^{1}$, Syeda Muntaka \\ Maniha ${ }^{1}$, Rashed Noor ${ }^{1 *}$ \\ ${ }^{1}$ School of Life Sciences (SLS), Independent University, Bangladesh (IUB), Plot 16, Block B, Aftabuddin Ahmed Road, Bashundhara, Dhaka 1229, Bangladesh
}

\begin{abstract}
The mass public health principally depends on types and qualities of a range of food items in any neighborhood. In this very study the microbiological analysis of the most sold bottled waters, fruit juices and dairy fluids consumed by the maximum children, carbonated soft drinks and the energy drinks especially consumed by young people was conducted with the simple isolation approach following the traditional microbiological methodology. Presence of Staphylococcus spp. was detected in $\mathbf{5 0} \%$ samples the results for the presence of enteric bacteria; fecal coliforms and Vibrio spp. were completely negative. On the basis of the quantification of total bacteria and of the staphylococcal species, more emphasis on the good manufacturing practice (GMP) as well as on the market complaints is suggested.
\end{abstract}

Key words: Microbiological quality, Bottled water, Fruit juices, Dairy fluids, Soft drinks, Energy drinks, Public health

For maintaining a sound state of public health over the country, one of the important steps is to well regulate the quality of different food items. Food safety has now become a major health issue since lots of cases have been found so far round the globe whereby mass people suffer from various disease outbreaks only due to microbiologically contaminated foods ${ }^{1-3}$. A range of microbiological study on different food items by different research groups round the globe revealed the association of food borne microorganisms with the studied samples. The predominant bacteria within the food samples has been reported to be Staphylococcus spp., the enteric bacteria, Vibrio spp., Aeromonas spp., Pseudomonas spp., Acinetobacter spp., Streptococcus spp., Bacillus spp., Listeria spp., Brucella spp., Campylobacter spp., Arcobacter spp., and Cronobacter spp., which were responsible for the food borne infection, intoxication and the toxicoinfection ${ }^{2,4}$.

Bangladesh is a highly populated country with the general lacking of knowledge on food safety within the mass people. The absence of awareness on general hygiene, lack of proper legislative bodies regulating the quality (detecting the microbial prevalence) of foods especially the newly launched items are the important barriers for the manufacturing and sales of quality food items in our country. In different foods bring about vital information on food safety as well as may envisage on the further intoxication caused by the prevailing microorganisms. Although to a few extent of food inspection is apparently being conducted; however, there are lots of evidences of food borne disease outbreaks including the enteric diseases especially diarrhea and bacteremia ${ }^{1-2}$.

Our previous works on the commercially localized food items including a range of street foods, fruit juices, milk and milk products, bottled waters and others showed a significant fraction of the studied items to be deleterious for public health ${ }^{5-9}$. Foods especially the liquid items including the bottled waters are good source for microbial growth and survival possibly due to the high water activity along with the nutrient exposure ${ }^{10}$. In this context, current study attempted to identify the present microbiological status of the commonly consumed liquid food items.

\section{Materials and Methods}

Sample collection: Five categories of samples of the commercialized products of bottled waters, fruit juices, dairy fluids, carbonated soft drinks and the energy drinks were collected from several shops in Bashundhara area of Dhaka city during the mid-August 2019. Representative and popular brands were chosen from each category. Products were transported to the Microbiology Laboratory of the School of Life Sciences (SLS) of Independent University, Bangladesh (IUB).

Microbiological analysis: Conventional microbiological methods were applied for the enumeration of bacteria within the chosen samples ${ }^{11-12}$. For the hetertrophic plate count (HPC) representing the total bacterial count (TBC), Luria-Bertani (LB) agar was used while for the detection of the specific bacterial species, different selective agar media were used ${ }^{6-8}$. As all the samples were liquids, $100 \mathrm{ml}$ from each sample was spread on the corresponding selective agar medium. Mannitol salt agar (MSA) was used for the isolation of Staphylococcus spp., MacConkey agar for Escherichia coli, Salmonella-Shigella (SS) agar for the detection of Shigella spp. and Salmonella spp., mFC agar plates for the detection of the fecal coliforms; and thiosulfate citrate bile salts sucrose (TCBS) agar for the isolation and enumeration of Vibrio

*Corresponding author:

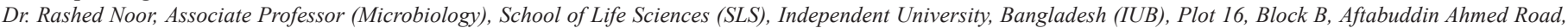
Bashundhara, Dhaka 1229, Bangladesh. Cell: +8801749401451, E-mail: rashednoor@iub.edu.bd 
spp. ${ }^{13}$. The $\mathrm{mFC}$ plates were incubated at $44.5^{\circ} \mathrm{C}$ while the other plates were incubated at $37^{\circ} \mathrm{C}$. For the fungal enumeration, potato dextrose agar (PDA) was used; and the incubation temperature was set at $25^{\circ} \mathrm{C}^{11-13}$. As a supporting way of measuring the microbial load, the membrane filtration method was also applied for examining all the samples.

Both the spread plate method and the membrane filtration method showed the similar results for all of the samples studied. Out of five brands of bottled waters, at least three were completely free from microorganisms while two brands were populated with staphylococcal species indicating the possible defect during the manufacturing of these items (Table 1). All the juice samples harbored heterotrophic bacteria with the abundance of only Staphylococcus spp. Abundance of microorganisms in juice samples is not unlikely possibly due to their high nutrient contents. Our previous work also showed such proliferation of staphylococci and even pointed the presence of coliforms ${ }^{6}$. However, in the current study, no sample was detected with coliforms. All the milk samples studied were dominated only by the staphylococcal species which is similarly indicative of defective handling during processing or packaging.

Around $40 \%$ of the carbonated soft drinks samples showed the prevalence of Staphylococcus spp.; and other specific bacteria were completely absent. Interestingly the branded "7 Up" sample showed no other bacterial presence except Azotobacter vinelandii
(Figure 1). Chalking out the possible sources of $A$. vinelandii would be of further interest. Besides, testing more samples for the detection of such bacterial presence is required. Around 50\% of the energy drinks showed the presence of Staphylococcus spp.; nevertheless, all were within the microbial limit ${ }^{14}$.

A couple of years back an estimation by the Taskforce on Food Adulteration (NTFS) in our country revealed that approximately thirty millions of Bangladeshi people suffer from the food borne complications ${ }^{1}$. Indeed the adulterated foodstuffs are highly responsible for casting the food borne enteric illnesses, leading to the dreadful fatality. Most of the food manufacturing companies utilize the good manufacturing practice (GMP) during production of any food items; however, the in process check (IPC), the quality control (QC) of the finished products; and most importantly handling the market complaints are also important to fully ensure the food quality ${ }^{10,14}$. There are two unfortunate reasons behind the food insecurity in mass aspect: (1) the insufficient microbiological analysis by the Governmental regulatory bodies like the "Bangladesh Standards and Testing Institution" (BSTI); and (2) understanding at customer level about the requirement of microbial analyses of foods. Such situations lead to the food borne disease outbreaks including food borne infections, intoxications and toxi-coinfections which actually remains unnoticed both by the sellers and the consumers. Therefore, researchers especially the microbiologists must focus on the

Table 1: Microbial enumeration of fluids and drinks sold in Bashundhara Residential Area

\begin{tabular}{|c|c|c|c|c|c|c|c|}
\hline Samples & & $\mathrm{HPC}$ & Fungi & $\begin{array}{c}\text { Enteric } \\
\text { Bacteria } \\
\end{array}$ & $\begin{array}{c}\text { Fecal } \\
\text { Coliform }\end{array}$ & $\begin{array}{c}\text { Vibrio } \\
\text { spp. }\end{array}$ & $\begin{array}{c}\text { Staphylococcus } \\
\text { aureus }\end{array}$ \\
\hline \multirow{4}{*}{$\begin{array}{l}\text { Bottled } \\
\text { water }\end{array}$} & $\operatorname{Mum}(\mathrm{n}=10)$ & $3.0 \times 10^{4}$ & 0 & 0 & 0 & 0 & $3.5 \times 10^{3}$ \\
\hline & Rangdhonu & $2.0 \times 10^{3}$ & 0 & 0 & 0 & 0 & $2.0 \times 10^{2}$ \\
\hline & $\operatorname{Spa}(\mathrm{n}=10)$ & 0 & 0 & 0 & 0 & 0 & 0 \\
\hline & Aquafina $(\mathrm{n}=10)$ & 0 & 0 & 0 & 0 & 0 & 0 \\
\hline \multirow{6}{*}{ Fruit juices } & Kinley $(\mathrm{n}=10)$ & 0 & 0 & 0 & 0 & 0 & 0 \\
\hline & Frutika $(\mathrm{n}=10)$ & $1.0 \times 10^{4}$ & 0 & 0 & 0 & 0 & $8.0 \times 10^{2}$ \\
\hline & Shezan $(n=10)$ & $2.6 \times 10^{4}$ & 0 & 0 & 0 & 0 & $6.0 \times 10^{2}$ \\
\hline & Pran Mango $(n=10)$ & $7.0 \times 10^{2}$ & 0 & 0 & 0 & 0 & $6.0 \times 10^{2}$ \\
\hline & Tropicana Apple $(\mathrm{n}=10)$ & $1.0 \times 10^{2}$ & 0 & 0 & 0 & 0 & 0 \\
\hline & Tropicana Mango $(\mathrm{n}=10)$ & $1.0 \times 10^{2}$ & 0 & 0 & 0 & 0 & 0 \\
\hline \multirow{3}{*}{ Dairy products } & Pran Lassi $(\mathrm{n}=10)$ & $1.0 \times 10^{3}$ & 0 & 0 & 0 & 0 & $3.0 \times 10^{2}$ \\
\hline & Arrong Mango Milk $(\mathrm{n}=10)$ & $1.0 \times 10^{4}$ & 0 & 0 & 0 & 0 & $2.0 \times 10^{3}$ \\
\hline & Milkman Chocolate $(n=10)$ & $1.0 \times 10^{3}$ & 0 & 0 & 0 & 0 & $1.0 \times 10^{3}$ \\
\hline \multirow{6}{*}{$\begin{array}{l}\text { Carbonated } \\
\text { soft drinks }\end{array}$} & $7 \mathrm{Up}(\mathrm{n}=10)$ & $0^{1}$ & 0 & 0 & 0 & 0 & 0 \\
\hline & Coke $(n=10)$ & $2.0 \times 10^{2}$ & 0 & 0 & 0 & 0 & 0 \\
\hline & Mountain Dew $(n=10)$ & 0 & 0 & 0 & 0 & 0 & 0 \\
\hline & Pepsi $(\mathrm{n}=10)$ & 0 & 0 & 0 & 0 & 0 & 0 \\
\hline & Zeera Pani $(n=10)$ & $2.0 \times 10^{3}$ & 0 & 0 & 0 & 0 & $7.0 \times 10^{2}$ \\
\hline & Current Energy $(\mathrm{n}=10)$ & $2.1 \times 10^{4}$ & 0 & 0 & 0 & 0 & $9.0 \times 10^{2}$ \\
\hline Energy drinks & Royal Tiger Energy $(\mathrm{n}=10)$ & $5.0 \times 10^{3}$ & 0 & 0 & 0 & 0 & 0 \\
\hline
\end{tabular}

$\mathrm{HPC}=$ Heterotrophic Plate Count; $\mathrm{n}=$ number of samples.

${ }^{1}$ Two samples showed the presence of Azotobacter vinelandii 


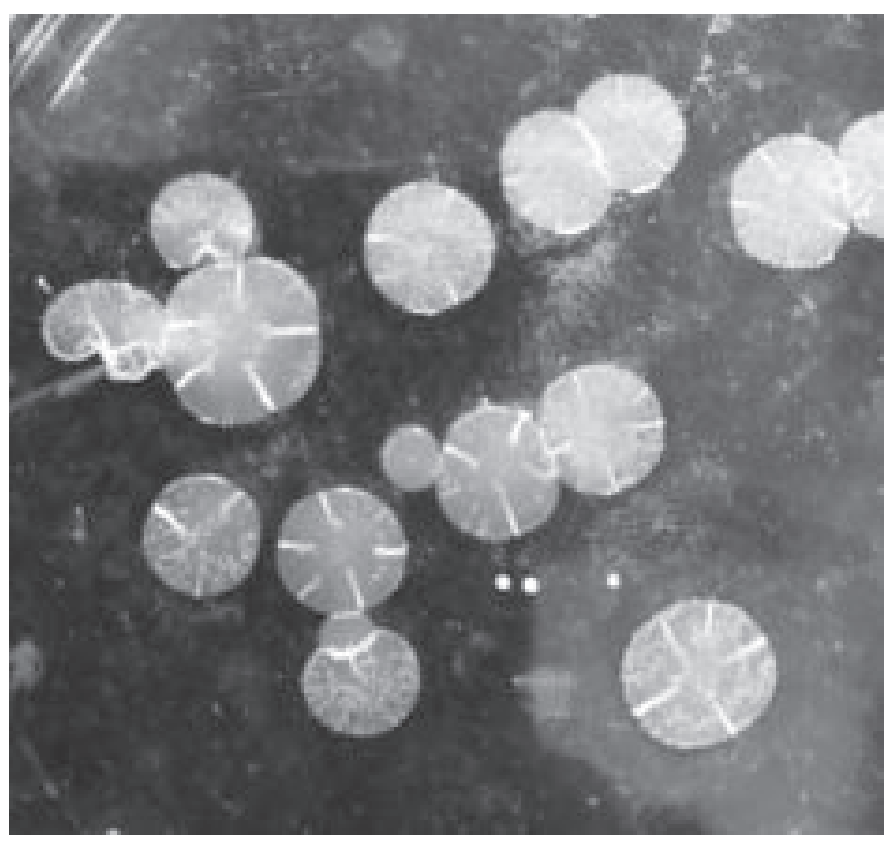

Figure 1. Azotobacter vinelandii isolated from two out ten samples of 7 Up carbonated soft drinks.

concept and application of HACCP (Hazard Analysis: Critical Control Points) in large scale during the manufacturing and packaging of the food items.

\section{Conclusion}

Current study on the liquid food items revealed more or less satisfactory results. However, the presence of staphylococcal spp. in $50 \%$ of the samples refers to the stringent adherence to GMP and QC during manufacturing and packaging of the commercial food items used by the mass people. Thus the effective management of quality from the microbiological perspective would be achieved which is vital for ensuring the consumer safety. The exceptional presence of $A$. vinelandii in some of the $7 \mathrm{Up}$ samples raised further interest to continue the study.

\section{Acknowledgement}

Authors are thankful to the Microbiology Laboratory of the School of Life Sciences (SLS) of Independent University, Bangladesh (IUB) for the logistic support.

\section{References}

1. Noor R and Feroz F. 2017. Food safety in Bangladesh: A microbiological perspective. S. J Microbiol. 6(1): 1-6.

2. Noor R and Maniha SM. 2019. Opportunistic food borne infections: A brief review. Acta Scientific Microbiol. 2(7): 67-71.

3. Noor R and Munna MS. 2015. Emerging diseases in Bangladesh: Current microbiological research. Tzu Chi Med J. 27(2): 49-53.

4. Chen CT, Yu JW and Ho YP. 2019. Identification of bacteria in juice/ lettuce using magnetic nanoparticles and selected reaction monitoring mass spectrometry. J Food Drug Anal. 27(2): 575 -584.

5. Noor R. 2016. Microbiological quality of commonly consumed street foods in Bangladesh. Nutrith Food Sci. 46(1): 130-141.

6. Noor R, Uddin MA, Haq MA, Munshi SK, Acharjee M and Rahman MM. 2013. Microbiological study of vendor and packed fruit juices locally available in Dhaka City, Bangladesh. Int Food Res J. 20(2): 1011-1015.

7. Acharjee M, Rahman F, Jahan F and Noor R. 2014. Bacterial proliferation in municipal water supplied in Mirpur locality of Dhaka City, Bangladesh. CLEAN - Soil Air Water. 42(4): 434-441.

8. Marjan S, Das KK, Munshi SK and Noor R. 2014. Drug-resistant bacterial pathogens in milk and some milk products. Nutritn Food Sci. 44(3): 241-248.

9. Sarker N, Islam S, Hasan M, Kabir F, Uddin MA and Noor R. 2013. Use of multiplex PCR assay for detection of diarrheagenic Escherichia coli in street vended food items. Am J Life Sci. 1(6): 267-272.

10. Noor R, Malek M, Rahman MS, Meghla M, Acharjee M and Rahman MM. 2015. Assessment of survival of pathogenic bacteria in raw fresh vegetables through in vitro challenge test. Int J Food Conta. 2: 15.

11. Atlas RM. 2010. Handbook of Microbiological Media, $4^{\text {th }}$ edn., pp $33487-$ 2742. Boca Raton, CRC Press, Florida.

12. Corry JE, Curtis GD and Baird RM. 2011. Handbook of Culture Media for Food and Water Microbiology. Royal Society of Chemistry, Cambridge.

13. Rahman F and Noor R. 2012. Prevalence of pathogenic bacteria in common salad vegetables of Dhaka Metropolis. Bangladesh J Bot. 41(2): 159-162.

14. Noor R, Zerin N and Das KK. 2015. Microbiological quality of pharmaceutical products in Bangladesh: current research perspective. Asian Pac J Trop Dis. 5(4): 264-270. 